\title{
'Enlisting in the struggle to be free': A feminist wrestle with gender and religion
}

\author{
Engajando-se na luta pela Liberdade: \\ uma batalha feminista com gênero e religião
}

Kochurani Abraham*

\begin{abstract}
This paper looks at the gendered underpinnings of religion using a feminist lens. It names the violence embedded in the gendered notions of religious ideology and praxis and shows how religion can be "injurious" to women's growth because of the following factors: the hierarchical dualism that alienates them from the Spirit and identifies them with the body while marginalizing them through their positioning on the lower rungs of the hierarchical ladder; the exclusive male imagery of God and its mediation by an all male priestly class and the scriptural injunctions which are inscribed by patriarchal thought and deployed to keep women in defined roles and spaces. Catholic teachings and practices are taken as a case of analysis to unearth the political dynamics by which religion reinforces 'gendering women's exclusion from theological knowledge making spaces and the gendered religious indoctrination which become hegemonic codes that shape women's consciousness and keep them without grievance in their subjugated status. It shows further how female body and sexuality are major sites of religious gender politics through the strict controls on women's dress-codes and the sexual servicing expected of them in marriage. Finally, the paper advocates critical thought as a tool for exploding the hardened rock of gendered religious foundations and shows how overcoming the contradictory consciousness and waking up to a critical consciousness becomes imperative for women to be freed of the gender dictates of religion.
\end{abstract}

Keywords: gender; religion; theological knowledge-making; sexuality; critical consciousness.

\section{Resumo}

Este artigo analisa os fundamentos de gênero da religião a partir de uma perspectiva feminista. Nomeia a violência embutida nas noções de género da ideologia e práxis religiosa e mostra como a religião pode ser prejudicial para o crescimento das mulheres por causa dos seguintes fatores: o dualismo hierárquico que as afasta do Espírito e as identifica com o corpo, marginalizando-as através do seu posicionamento nos degraus mais baixos da escala hierárquica; o imaginário masculino exclusivo de Deus e sua mediação por uma classe sacerdotal exclusivamente masculina assim como as interdições bíblicas inscritas no pensamento patriarcal e implantadas com o objetivo de manter as mulheres em seus papéis e espaços definidos. Ensinamentos e práticas católicas são considerados como um caso de análise para descobrir a dinâmica política pela qual a religião reforça a exclusão de gênero das mulheres de um possível saber teológico e a doutrinação religiosa de gênero que se tornam códigos hegemônicos que moldam a consciência das mulheres, mantendo-as amordaçadas em sua condição de subjugadas. Além disso, mostra como o corpo feminino e sexualidade são os principais locais das políticas religiosas de gênero através dos controles estritos sobre os códigos de vestimentas das mulheres e os serviços sexuais que se esperam delas no casamento. Finalmente, o artigo defende o pensamento crítico como uma ferramenta para explodir a rocha endurecida das fundações religiosas de gênero e mostra como superar a consciência contraditória, despertando-nos para uma consciência crítica que se torna imperativa para que as mulheres possam ser liberadas dos ditames de gênero da religião.

Palavras-chave: gênero; religião; criticidade teológica; sexualidade; consciência crítica.

Article received on May 17, 2015, and approved on September 28, 2015.

* Dr. Abraham is an Indian feminist theologian, researcher and writer on issues related to gender. País de origem: Índia. E mail: kochuabraham@gmail.com

Horizonte, Belo Horizonte, v. 13, n. 39, p.1296-1314, July/Sept. 2015 - ISSN 2175-5841 


\section{Introduction}

In one of my fieldwork trips a couple of years ago to a catholic village in Kerala, South India, I was invited to attend the annual meet of a Family Unit ${ }^{1}$ of that area. The speaker of that function, a recognized lay preacher of that diocese- a man in his mid forties, chose to speak on the crisis affecting marriage and family life in Kerala. ${ }^{2}$ Curiously, the text he selected for the occasion was the story of the Prodigal son from the Gospel of Luke. According to his reading of the story, the Gospel text had a very direct message for women living family life. The son became prodigal because there was no mother or sister in that family to accompany him in the process of his growth. For that preacher, this was very true of the Kerala context as women of the younger generations opted for career more than family responsibilities and related commitments.

This interpretation of the story of the prodigal son could be taken as betraying the shallowness of a naïve 'charismatic' preacher, and could be written off as 'ridiculous' by anyone who has a basic understanding of biblical texts in relation to their contexts. However, the comments by some of the simple women gathered there who opined that they had never thought of such an 'insight' from that particular text indicated that the preacher was successful in his mission. He had accomplished his goal in making many women feel confused and guilty for any form of crisis experienced in their families.

India is a very religious country as people, particularly women continue to be faithful practitioners of religion. As far as Christianity is concerned, the Church services both in the urban and rural setting continue to be well attended, with women making up the majority of the faithful at these services. Even within the

\footnotetext{
${ }^{1}$ Family Units in the catholic set up in Kerala is something akin to the Basic Christian Community (BCC) unit in other parts of the world, where a catholic parish is divided into smaller units for the purpose of building greater fellowship among the families of the parish. These units meet together once a month for prayer and fellowship.

${ }^{2}$ As per the state government figures, there has been a steady increase in the number of divorce petitions that had reached the Family Courts in Kerala. It was 8,456 in 2005-'06; 9,775 in 2006-'07; 9,937 in 2007-'08; 11,194 in 2008-'09; 11,600 in 2009- '10; 24,815 in 2010-'11; and a total of 44,236 divorce petitions have reached before various courts in the State between January, 2011 and January, 2012. The present statistics is not available, but divorce petitions are wildly on the increase that there are moves to set up two family courts each in each district of the State.
} 
broader framework of Hinduism, women are the mainstream temple goers and transmitters of tradition. In such a 'religious' setting, women take pride in being the loyal transmitters of piety and religious faith, and so, the danger lies in their blindness to the tactics of patriarchy that uses their 'religiousness' to keep them subjugated and well contained within the restricted spaces allotted to them.

It is within this framework that I have titled this paper 'Enlisting in the struggle to be free' borrowing this idea from Paulo Freire's 'pedagogy' of the oppressed (FREIRE, 2009). Women need to join in this struggle for freedom with a critical feminist consciousness and so, this paper attempts to look at the gendered underpinnings of religion using a feminist lens, focusing mainly on the Hindu and Christian traditions. It names the violence embedded in the gendered notions of religious ideology and praxis, and then examines critically the gender politics of religion as evident in women's exclusion from theological knowledge making and in relation to female body/sexuality. Finally, the paper advocates critical thought as a tool for exploding the hardened rock of gendered religious foundations.

\section{Violent Ambiguities of the Religious Genderscapes}

From the times of old, women have been socialized to be religious. It has been inculcated into their minds that piety is a feminine quality that characterizes the 'good woman'. Since religion has been taken to be representing the 'higher' aspects of life, women have been mislead to believe that they are a privileged lot, called to follow diligently and transmit faithfully this 'superior' aspect of human existence to future generations. And women have engaged in religious practices blissfully ignorant of the damage it can cause to their growth as human persons in their own right.

How is religion "injurious" to women's growth? This question may seem outrageous to many who are devotedly religious, all the same, it is a matter of much concern to anyone serious about women reclaiming the fullness of their 
humanity. We shall examine few aspects in the mainstream religious ethos that are detrimental to women's growth and wellbeing.

Most of the established religions function on a dualistic thinking pattern, whereby the 'spiritual' is set against the corporal and is taken to be superior to the material or earthly realities of life. Even as women are expected to be spiritual in the practice of piety, women's body and sexuality are identified with the flesh positioned against the spirit that is mediated solely by male beings. In the bargain, women remain spiritually infantile, conditioned by the male mediated belief systems and spirituality. In all the established religions which are inscribed by patriarchy, women are always at the receiving end, their task mainly to execute the established religious norms and practices.

Adding to the harmful outcome of dualistic thought on women, are the effects of their location on structures that mark religious systems. Hierarchy being a key feature of religious exercise of power, and women's positioning being on lowest rungs of the hierarchical ordering of power relations, the obvious outcome is the situation where women are subjugated and marginalized. Within the fetters of this structural positioning, women are at the losing end even as they uphold the system through their uncritical assimilation of religious doctrines and their naive conformity to the expected practices.

Besides the constraints of hierarchical dualism, the exclusive male imagery of God and its mediation by an all male priestly class affect women negatively even though they are oblivious of it. The lasting effects of this adverse experience express itself in women becoming incapacitated to image the divine and in their alienation from what is taken to be representing the sacred dimensions of life.

Greater harm is inflicted through the many Scriptural injunctions which women take as divinely ordained, being unaware of the patriarchal tactics deployed through them to shape their consciousness and keep them in defined 
roles and spaces. Even when these injunctions are evidently violent, women tend to remain blind to its ploy because they are coated in religious shades. Startlingly, there are some marked similarities in the women related or gendered injunctions of the western and eastern religious traditions. I take some examples from the Hindu and the Christian tradition to illustrate this point.

The Manusmruti3, an ancient law code of the Hindu tradition has many misogynic and violently gendered statements. Dependency of women on men is made explicit when it says: "Girls are supposed to be in the custody of their father when they are children, women must be under the custody of their husband when married and under the custody of her son as widows. In no circumstances is she allowed to assert herself independently."(Manu 5/151). The law code defines women's sole existence in terms of a life of servitude when it says: "Women have no sacrifices of their own to perform, nor rites, nor observances to pursue. Obedience to husbands alone would exalt the woman in heaven"(Manu 5/158). Worst still, it expects of women unconditional fidelity even in most culpable situations: "Men may be lacking virtue, be sexual perverts, immoral and devoid of any good qualities, and yet women must constantly worship and serve their husbands"(5/157).

While the Christian Scriptures are not that explicitly violent in its gendered dictates, we find some parallels of Manu in the Epistles of the Second Testament. The Pauline injunctions on how women ought to conduct themselves, though written to particular communities in response to certain contextual issues, continue to have an impact on women's gendered identity and roles in the Churches. The dictates on women's silence, their subjection to their husbands and the assertion that man is the 'head' (cf. Col. $3: 18$; 1 Cor 14: 333-35; 1Tim 2: 9-15) serve as hegemonic codes that continue to have a subjugating effect on women particularly in cultures where religion is a major factor of personal and communitarian life. These reflect the dependency codes of Manu, which does not envisage for women an autonomous space or existence. Religious violence of this

\footnotetext{
${ }^{3}$ Manusmruti is a discourse given by Manu, considered the originator of humankind to a group of seers who beseech him to tell them the "law of all the social classes". According to Hindu tradition, the Manusmruti records the words of Brahma or God.
} 
nature being slow, vague and elusive, women generally do not perceive this as something detrimental to their lives.

The interplay of gender and religion is a key factor in the politics4 (LESLIE, 2000) of social definition, in the ascription of social space, and in the shaping of women's consciousness. The irony of the situation is that even when the hegemonic codes of religion delineate women's social boundaries through the notions of purity and pollution, and serve to define their status in terms of dependency on male protection, women perceive religion as positively providing them succour and relief. As opined by social theorists, the most insidious form of power is the force or ideology which shapes one's mindset in such a way that that they uncritically accept their role in the existing order of things and are prevented from having grievances (LUKES, 1974). Religious indoctrination tends to shape women's perceptions, cognitions and preferences in such a way that they assimilate the 'contradictions of the social order'5 (BAUM, 1975) as natural or as divinely ordained and fail to see or imagine any alternative to it.

\section{Unearthing the Gender Politics of Religion}

In order to unearth the political dynamics by which religion reinforces 'gendering', ${ }^{6}($ OAKLY, 1972) I take the Catholic Church's teachings and practices as a case of analysis. In this paper, this is examined from two angles: the gendering of religious knowledge making and the question of female body/sexuality in relation to religious gender politics7 (ABRAHAM, 2014).

\footnotetext{
${ }^{4}$ The terms politics is deployed here to indicate the methods, practices and ideologies used by an individual or group to assert and gain control and power over another.

${ }^{5}$ Marx regarded religion as the product of alienation inflicted on human life by the contradictions of the social order.This verdict seem to find realization in women when they deal with the unresolved and shadowy side of their lives with the strength they find in religious beliefs and rituals.

${ }^{6}$ By gendering is meant the internalization of the constructed differences by the sexes which gets normalized as the way of being women and men.

${ }^{7}$ This section is taken from a paper presented at a National Conference on 'Religion in Public Life' organized by the Department of Christian Studies, University of Madras, India.
} 
In the Catholic setting, it was during the Second Vatican Council (1962-65) that the question of women' absence in the theological knowledge-making spaces was raised first. At the end of the second session of the Second Vatican Council, Cardinal Leo Jozef Suenens of Belgium seem to have asked his fellow bishops: "Why are we discussing the reality of the Church when half of the Church is not even represented here?"In response to this critical observation, at the 3rd session of the Council which began in 1964, 23 women were invited as auditors. Though this was a Council which was decisive in charting the future course of the Church, these women auditors had no voting rights or a direct say in the theological deliberations held there. A 1996 publication that recounts the experiences of these women auditors, titles the book as Guests in Their Own House: The Women of Vatican II ( MCENROY, 1996). Interestingly it is reported that shortly before his death, Cardinal Suenens finally gave credit for most of his ground-breaking ideas-to Veronica O'Brien, an Irish woman, whom he called "the left hand of God." She had spent some years in a convent, then moved to continental Europe, where she became the right hand of Suenens by furnishing him with innovative ideas, which he passed on to the Council (SUENENS, 1963).

Fifty years later, the scenario has not changed dramatically. A gender audit of some of the seminars/symposiums organized by some recognized theological faculties in India gives further insights into the gender politics of religion. At a national theological conference organized by a reputed Athaneum of Theology and Philosophy in India, which was in fact celebrating the fifty years of Vatican II on the theme Faith, Reason and Wisdom, the programme had a woman speaker only for giving a 'feminine' perspective to the discourse, while all the other perspectives like the scriptural, theological, philosophical, the perspective of science, folklore, human resources and the like were given by men. This arrangement betrayed the gendered association of the feminine only with femaleness and the masculine with maleness and the dominant production of knowledge.

\footnotetext{
${ }^{8}$ According to the author of this book, within 20 years of the closing of Vatican Council II, the fact that there were any women at the Council was already becoming a forgotten memory. In 1986, an English Benedictine scholar Alberic Stacpole wrote a book titled Vatican II Revisited by Those Who Were There. However, there was not a single article by one of the 23 officially invited women auditors. This exclusion motivated her to write the book in order to recover the dangerous memory of the female auditors before it was irretrievably lost.
} 
What is evident in a gender audit of any such religious programme is that theological knowledge making of mainstream religions continues to be a highly gendered activity. The issue at stake is that when religions understand gender in an essentialist manner, gender difference is taken to be genetically determined with the notion that each gender carries with it a set of physical, emotional and psychological characteristics. Within this frame of reference, the relational aspect of gender categories produces and sustains binary opposites invoked in stereotypical ways: masculinity/femininity, active/passive, rational-emotional and the like (KEHILY, 2002). In this respect, rationality becomes a male privilege while caring gets eulogized as a female prerogative. Though many women are competent and well prepared for knowledge-making processes, their intellectual capabilities informed by the wisdom acquired from years of practical experience do not get recognized. And so, at the theological knowledge-making and knowledge transmitting spaces of religion, women's presence and contributions-if at all they are present- are utilized mainly for a garnishing purpose, in an add woman, stir and serve fashion.

The term gender can used to analyze the roles, responsibilities, constraints, opportunities and needs of women and men in all areas and in any given social context. Gender roles are learned behaviours in a given society, community or other social group. They condition activities, tasks and responsibilities are perceived as male or female (ILO, 2000). A brief scanning of the Church documents of the last few decades further illustrates the gender politics of the Church which on the one hand affirms woman as being equal to man before God, while holding on to a rigid notion of gender marked by essentialism. While the 1963 encyclical Pacem in Terris spoke of women coming into public life as one of the 'signs of the times', and the Decree on the Apostolate of the Laity of the Second Vatican Council urged that women's participation in the various sectors of the Church's apostolate should develop in keeping with their active engagement in the whole life of society (AA9), the 1988 Apostolic Letter Mulieris Dignitatem of Pope John Paul II spelt out motherhood and virginity as two particular 
dimensions of women's vocation. 9 This stance was further reiterated in the Letter of John Paul II to Women on the occasion of the 1995 Beijing Conference where he expresses gratitude to every woman for her vocation and mission in the world and for all that they represent in the life of humanity. What is ironic here is that the Pope addresses women by the customary gender stereotypes of wife, mother, daughter, sister and consecrated woman/sister. The 2004 Letter of the Vatican congregation for the doctrine of Faith on Collaboration of Men and Women in the Church and in Society has become most conspicuous in this regard. It falls back to biological essentialism, taking biological sexual differences as the base for a total ontological and spiritual difference between males and females, and takes women's "essential nature" as being for others. Besides, it is founded on a theological anthropology that is based on the analogy that male is to female as God is to human.

Coming to the present times, the situation has not changed much. Even the recent 2013 document- Evangelii Gaudium of the present Pope Francis, falls back on biological essentialism in its understanding gender as he speaks about "sensitivity, intuition and other distinctive skills which women, tend to possess more than men, and mentions "the special concern which women show to others, which finds a particular, even if not exclusive, expression in motherhood." It is unfortunate that the Pope cannot identify intelligence, organizing abilities, leadership skills and the like in women, though he points out to the "need to create still broader opportunities for a more incisive female presence in the Church.” In the same document, the question of reserving priesthood to males is reiterated 'as a sign of Christ the Spouse who gives himself in the Eucharist'. This once again is a highly gendered discourse as it seems to say that the priest must be male as Jesus was male and so, only males can image Jesus Christ. While it is added that the 'configuration of the priest to Christ the head' does not imply an exaltation which would set him above others, gendering of the discourse is at its peak in stating that

\footnotetext{
${ }^{9}$ Numbers 17-22 of Mulieris Dignitatem is dedicated to explain theologically the essential vocation of women as mothers and as virgins.
} 
Mary, a woman, 'is more important than the bishops.' (EVANGELII GAUDIUM 103 e 104).

I am not entering into the theological underpinnings of comparing Mary 'a woman' to the Bishops, but interestingly this is again clearly indicative of the gender politics of religious discourse. Discourse, in the Foucaldian sense can be explained as ways of knowing and understanding the world, and through discourses evolve 'discursive practices' which are processes, patterns or ways of operating, which can be deployed to observe and define individuals or groups (KEHILY, 2002). Marian discourses are conveniently deployed to define women's role in the Church. Discourses hold tremendous power to mould the consciousness of people and in a religiously motivated gender discourse, gender politics operates in making women and men believe that the gender divide and its associated attitudes and roles are divinely ordained. Christian theological anthropology succeeds in this task by affirming that women and men are equal in dignity as both are created in the image and likeness of God, but with differences. Essentializing the differences become the 'prescriptions' that give religious legitimization to the hierarchical and dualistic thinking that inform power equations beneath gender relations in the Churches and society today.

The Magisterium or the teaching authority of the Church, which is an exclusively male body holds the reins of discourse. A gender audit of the 2014 Vatican Synod on the Family is another illustration of the gender politics of religious discourse. Though the focus of the Synod was on the family, and the Church has repeatedly insisted that women play a key role in sustaining the integrity of the family, the women participants to the Synod were a token representation of 24 women. The rest were male celibate clergy and bishops with the exclusion of some lay men who are among the 14 couples invited from the whole world to participate in the Synod. Within the given gender ideology that informs the Churches, it is not surprising that women are given to articulate or perform roles that are basically seen as performing a decorative function and as being marginal to the Church's theological growth and development. 
In the Churches that continue to exclude women from priestly ministry, there is an association of sacredness with the male body and consequently with leadership roles as positions of authority are linked to ordination. Women's position in these Churches has been inextricably linked with the conceptualization of the body, where women's bodies are seen through the lens of the profane and the carnal, and denied the 'sacred' role of mediating Jesus Christ. Monica Furlong who has done extensive study on the question of the denial of ordination to women observes that where women have sought an equitable place, they have been defined in 'dangerous' terms as an "ineradicable virus in the bloodstream" (FURLONG, 1988).

When religion sees women primarily through a gendered lens, their exclusion from leadership and knowledge/decision-making roles is countered by their greater inclusion in the service ministry marked by care-nurture roles. At the end of a Catholic service in which I participated recently, the priest made a very explicit gendered invite to the members of his parish community. He announced about a meeting where they had to decide about the construction of a parish hall and the men of the community -as heads of the families- were urged to attend it without fail. Continuing the announcements, the priest mentioned about the forthcoming jubilee celebrations of the institution of the parish. For this occasion, he made an explicit request to the women of the community to prepare and bring a

particular sweet from each home for sharing with the whole community. I found an ironic smile on the faces of many women, that seemed to express the satisfaction of being wanted at least for the 'sweetening' roles in the Church. To me, this was a further confirmation of how the mind-body polarity theologized as 'complementarity' in the roles attributed to men and women, continues unabated in the pastoral praxis of the Churches even today. 


\section{Gendering of Female Body/Sexuality in Religious Politics}

One of the major sites of religious gender politics is the female body and sexuality. Christian tradition has been tainted by the many misogynic statements which attempted to make a woman think that she "should be filled with shame by the thought that she is a woman."10 As history unfolded, even though women have been reluctant to take in such pronouncements in its face value, the destructive effects of such gendered discourses of religion have become apparent in different degrees. It has varied from the consideration of women's bodies as inevitable evil to inculcating in women a sense of unease towards their own body and sexuality.

We find misogyny echoing also in the Hindu tradition particularly in relation to female body and sexuality. As per the Brahminical gender codes, women's essential nature or strisvabhava is identified with their sexuality and the Hindu religious texts represent women's sexuality as sinful and even as a threat. According to Tryambaka's version of Manu's 'Stripumdharma', women are innately promiscuous, fickle minded, lacking in love and unfaithful to their husbands even when closely guarded. (Manu Dharma Sastra IX: 17).The same pattern of thinking is reflected in the great epics of Hinduism. The Ramayana considers women as essentially weak and sinful, their hearts inconsistent and uncaring for the good of the family ${ }^{11}$ (MOHANTY, 2004). This notion also appears repeatedly in the ancient text of Mahabharata as it emphatically states that 'the cunning tricks of demons are known to be unique to women'12 (MOHANTY, 2004). It is observed that desire (kama) and control (yoga) had become a major opposition that structured the Hindu worldview from the time of the Upanishads. Women and the divine apsaras who attempted to seduce the ascetics represented the former, and men represented the latter (YOUNG, 2002).

\footnotetext{
${ }^{10}$ Saying attributed to $2^{\text {nd }}$ Century Father of the Church, Clement of Alexandria.

${ }^{11}$ Cf. Ramayana of Valmiki II.39.236-40 cited by Chakravarti in "Conceptualizing Brahminical Patriarchy in Early India: Gender, Caste, Class and State.

${ }^{12}$ Mahabharata XIII.39.5,
} 
Manu, the most prominent ideologue of the Brahminical system addresses the so called 'congenital fickleness of women's nature' in ruling that they be guarded day and night regardless of their age. Manu's argument is that by carefully guarding the wife, a man preserves the purity of his offspring, his family, himself and his means of acquiring merit.(Manu Dharma Sastra IX: 7). This obsession with women's chastity is clearly an expression of the caste inscriptions of religion, since 'caste' purity is sustained by exercising controls on women's sexuality. The spillover of such patriarchal gender dictates is felt even today particularly through the controls exercised on women's dress codes and other restrictions on their mobility (WILFRED, 2009).

While in the West, the religious controls on women's bodies seem to have loosened due to secularization and other factors over the last few decades, within the Eastern cultural framework, religions continue to have say on who a woman is and how she ought to conduct herself in public life. In the Asian context, particularly where the Oriental Christian tradition is strong, the scriptural injunction that women 'cover their heads' is strictly followed in the Churches. In spite of the changing role of women in the wake of the $21^{\text {st }}$ century, due to women's inability to distance themselves from the religious ethos or view critically the patriarchal inscriptions of religious indoctrination, religious sexual politics continue to have a say in moulding their consciousness.

In India, religious discourses relating to women's body and sexuality have become more forceful in the wake of the 'rape epidemic'13 in the recent past. Besides the intensified moral policing by religious fundamentalists, many persons in religious leadership apparently have a definite solution to the problem of sexual violence. They suggest exercising strict controls on women's mobility and dressing as a definite way out of the problem. A greater vigilance on the dress-codes of the female sex is done under the pretext that a girl/woman's dressing is one of the major factors behind the increased incidence of rape in India. In many Churches,

\footnotetext{
${ }^{13}$ After the gruesome gang rape and the death of a young para-medical girl student at New Delhi in December 2012, sexual violence against women have been reported in such a shocking frequency, that it has given the impression of the outbreak of a rape epidemic in the country.
} 
girls are told explicitly to dress very modestly to avoid rape. Parents, teachers and those in religious leadership who are concerned about their daughters' safety are incessantly making 'modesty' prescriptions for their protection, not realizing that the roots of the problem lie elsewhere. And a great majority of women become faithful practitioners and transmitters of these norms of modesty, particularly in the rural setting of India where the practice of religion is strongest. Having internalized the patriarchal injunctions, women take upon themselves the task of self-policing in the Foucaldian sense of panopticon and teach the younger generation to comply by these hegemonic codes in order to avoid trouble.

Social definitions of gender as ascribed primarily on the female body through dress-codes reflect the meanings attributed to female sexuality. Social and cultural factors like religion and caste also intersect with gender in determining how a female body ought to conduct itself in public and in the private spheres. Data from my recent research on Higher Secondary youth is revealing of how deeply even the younger minds are ingrained by these social prescriptions of female body and sexuality. Of the respondents, 93 percent boys and 87 percent girls think that girls and women should follow strict dress-codes, because they consider that it is the right way of being and going about things. In addition, 63 percent boys opine that girls or women are raped because of immodest dressing while only 32 percent girls share in that opinion, the difference in perception between boys and girls being highly significant from a statistical point of view. This discrepancy in the perception of boys and girls on the question of women's dressing as a stimulus to rape, calls for serious rethinking on the formation of masculinities. This is an issue that requires a deeper analysis, and so, it is beyond the scope of this paper.

The gender politics of religion inscribing women's body and sexuality finds stronger footing within the establishment of marriage. In the Indian context, marriage has been traditionally upheld as a 'stable' institution that is not rocked by the changing influences of modernity. However, with the alarmingly increase in 
divorce petitions reaching the family courts of the country, the pangs of 'crisis' affecting the institution of marriage is increasingly felt. In this context, painstaking attempts are made by the mainstream religions to 'save' marriage from the impending disaster of a breakdown, their prescriptions mainly reinforcing the gendered power equations between women and men.

Within the Catholic tradition, even though modern exegetes attempt to give new explanations to Ephesians 5: 21-33 in view of legitimizing its usage as a key text on the theology of marriage, ${ }^{14}$ (LINCOLN, 1990) feminist theologians find the Christ-Church imagery to symbolize man-woman relations posing a serious problematic as it legitimizes women's subjugation to their husbands and justifies unequal gender relations in family life (OSEK, 1992). The disastrous effect of this Pauline typology of marriage on those who are serious about their religious doctrines and its practice can be illustrated by my own research on the Catholic Syrian Christian women of Kerala. 15 On a query about marital relations, 73 percent of the respondents opined that on the question of sexuality, husbands exercise authority over wives, and that they feel obliged to satisfy husband's every need on bed 16 (ABRAHAM, 2001). For many women, 'sexual servicing' is a sacred duty expected of them in marriage.

The question as to whether marital rape is to be considered a legal offence is strongly debated in India today. There were heated discussions around the comments made by a minister of state in the Upper House of Parliament on April 29, 2015, who opined that since marriage is perceived as a sacred union in India, marital rape cannot be included in the rape law. Women's rights activists have expressed strong protests to this standpoint, as they find that against the backdrop of gruesome stories of sexual abuse experienced by very many married women in

\footnotetext{
${ }^{14}$ Some of these exegetes justifying the Christ- Church analogy for nuptial symbolism argue that the exhortation of the wife's 'submission' to the husband (Eph 5: 22) ought to be read along with the earlier verse which implies that submission is mutual, reciprocal and shared in the "fear of Christ" and in stating that the husband is the "head' Paul does not use the word arche here suggesting a leader or commander in the sense of domination but kephale which connotes the position like a capstone in architecture.

${ }^{15}$ The Catholic Syrian Christians are one of the three catholic ritual communities in India, a community that traces its origins to St. Thomas the apostle, who, as per this tradition brought Christianity to the Indian soil in the first century and founded this community.

${ }^{16}$ See the unpublished doctoral Thesis of Kochurani Abraham titled "Between Patriarchy and Development: Power Negotiations of Catholic Syrian Christian Women of Kerala", done under the supervision of Prof. Dr. Felix Wilfred, in the Department of Christian Studies, University of Madras, 2011.
} 
India today, playing the religious card becomes a safe mask. They argue that this 'sacred' mask be removed from the face of marriage and the issue be addressed squarely in its complexity. As observed by feminist lawyer Flavia Agnes, even if the government brings in the amendment to include marital rape in rape law as being demanded by the campaigners, it will not bring any change into women's lives unless they have a strong support base, and the society stops viewing marriage as the be all and end all of a woman's life. (AGNES, 2015; RAMLAN; JALIL, 2015)17

In this situation, it is important that women learn not to compromise and endure the many forms of violence within marriage behind the shield of religion. For this learning to happen, a radical re-positioning with regard to how they see themselves becomes necessary. Women's experience of subordination makes them susceptible to a contradictory consciousness in their efforts to cope with their situation. As social theorists observe, contradictory consciousness manifests when social groups find it difficult to dispute the hegemony of other groups or challenge the cultural concepts that stigmatize them. Politically weak, they may not be in a position to disagree with the constructions of reality that more dominant groups produce and disseminate, instead they may even conspire with the dominant culture to make the social order that oppress them appear objective and unalterable, natural and moral and even just (PARISH,1997). In such situations, instead of striving for liberation, they tend to become oppressors or 'suboppressors' themselves, and they have no consciousness of themselves as members of an oppressed class (FREIRE,1970).

Overcoming the contradictory consciousness and waking up to a critical consciousness becomes crucial if women are to be freed of the gender dictates of religion. For this to happen, women need to engage in critical thinking about the different systems of knowledge and power that legitimize their subjugated status in the name of gender, however sacrosanct they may appear to be. As pointed out by

\footnotetext{
17 See Flavia Agnes, "Marriage is Not Sacred" in Asian Age, 8 May 2015. There are reports of Muslim women being confused about their sexual rights in marriage. See Yasmin Ramlan And Melati A. Jalil, "Young Muslim women still fuzzy about sexual rights in marriage in The Malasian Insider, 1 May 2015.
} 
Paulo Freire, a critical consciousness enables the oppressed to perceive the reality of oppression, not as a closed world from which there is no exit, but as a limiting situation which they can transform. This perception enlists them in the struggle to free themselves (FREIRE, 1970). Women need to develop a critical consciousness in order to understand this pedagogy and discover for themselves a path that is transformative.

\section{Conclusion}

It is an indisputable fact that the mainstream religions are strongly wired by patriarchy and gender is a key factor in the persistence of patriarchal conditioning. When women begin to ask critical questions about themselves, their world, their God and life at large, they challenge the gendered socio-cultural systems of thought and practice. Personal and collective engagement in this questioning will help develop a genderquake, which is decisive for shaking the established foundations of religious patriarchy.

Shudders of this quake are beginning to be felt with the emergence of feminist thought and its attempts to de-gender humans of the oppressive shackles of gendering. A recent statement by someone in Church leadership who acknowledged gender theory as a new horizon for some, but "a nightmare for the Church" (Beattie, 2015) is a clear indication of the impact of genderquake on religions today. What is threatening is that when women suspect some anomaly in the age-old definitions of gender, religions begin to lose their grip on women, and consequently their hold in the naturalization of gender hierarchies. Denaturalization of gendering demands that women get enlisted in the struggle to free themselves' so that religious mediation of patriarchy ceases to be a defining factor in their lives. 


\section{REFERÊNCIAS}

ABRAHAM, Kochurani .Between Patriarchy and Development: Power Negotiations of Catholic Syrian Christian Women of Kerala. 2011. Thesis (doctoral) - Department of Christian Studies, University of Madras, 2011.

ABRAHAM, Kochurani. Gender Politics of Religion: A Feminist Theological Appraisal. Indian Journal of Christian Studies, Índia, v. 4, n. 1-2, p. 39-56 January -December 2014.

ABRAHAM, Kochurani. Women Encounters with Religion: Gendered Landscape of Violence, Ambiguity and Emancipation. In: WILFRED, Felix (ed.). Transforming Religion: Prospects for a New Society. New Delhi: ISPCK 2009.

AGNES, Flavia. Marriage is Not Sacred. Asian Age, 8 May 2015. Available at: < http://www.asianage.com/columnists/marriage-not-sacred-614>. Access in: 10 May 2015.

BAUM, Gregory. Religion and Alienation: A Theological Reading of Sociology. New York: Paulist Press, 1975.

BEATTIE, Tina. God is a Feminist Issue. The tablet, 9 May 2015, p.8. Available at: < http://www.thetablet.co.uk/letters-extra/12/5587/god-is-a-feminist-issue >. Access in: 10 May 2015.

CATHOLIC CHURCH. Pope (1978-2005: John Paul II). Letter encyclical of John Paul II to Women. Bombay: Pauline Publications 1995, n. 2.

CONGREGATION OF THE DOCTRINE OF FAITH, Letter to Bishops on Collaboration between Women and Men in the Church, 31 Jul. 2014.

FRANCIS, Pope. Evangelii Gaudium. Vatican: Liberia Editrice Vaticana, 2013.

FREIRE, Paolo. The pedagogy of the Oppressed. New York: Seabury Press, 1970.

FURLONG, Monica Furlong (ed.). Mirror to the Church: Reflections on Sexism. London: SPCK, 1988.

ILO. ABC Of Women Worker's Rights And Gender Equality. Geneva: International Labour Office, 2000.

JOHN PAUL II, Pope. Mulieris Dignitatem. Bombay: Pauline Publications 1995

KEHILY, Mary Jane. Sexuality, Gender and Schooling: Shifting Agendas in Social Learning. London and New York: Routledge, 2002.

LESLIE, Julia; MCGEE, Mary (ed.). Invented Identities: The Interplay of Gender Religion and Politics in India. New Delhi: Oxford University Press 2000. 
LINCOLN, Andrew T. Word Biblical Commentary Vol. 42: Ephesians. Dallas: Paternoster Press, 1990.

LUKES, Steven. Power a Radical View. London: Macmillian Education ltd, 1974.

Mahabharata XIII.39.5 cited by Chakravarti in Conceptualizing Brahminical Patriarchy in Early India: Gender, Caste, Class and State apud MOHANTY, Manoranjan (ed.). Class, Caste, Gender. New Delhi: Sage Publications 2004.

MCENROY, Carmel. Guests in their own House: Women of Vat II. New York: Crossroad Publishing Company, 1996.

OAKLY,Anne. Sex, Gender and Society. London: Harper Colophone Books, 1972.

OSEK ,Carolyn. The Bride of Christ(Eph. 5: 22-33) A Problematic Wedding In: NISSINEN, Marti;URO, Risto (ed.).;LAKE, Winnona. In: JOHNSON, Elizabeth. Ephesians, Eisenbrauns, 2008 . In: NEWSOM ,Caron A.;RINGE, Sharon h.(ed.). Women's Bible Commentary, Louisville KY: Westminister/John Knox Press 1992.

PARISH, Steven. M. Hierarchy and its Discontents: Culture and the Politics of Consciousness in Caste Society, Delhi: Oxford University Press, 1997.

RAMAYANA OF VALMIKI II.39.236-40 cited by Chakravarti in Conceptualizing Brahminical Patriarchy in Early India: Gender, Caste, Class and State apud MOHANTY, Manoranjan (ed.). Class, Caste, Gender. New Delhi: Sage Publications 2004.

RAMLAN, Yasmin; JALIL, Melati A. Young Muslim women still fuzzy about sexual rights in marriage. The Malaysian Insider, 1 May 2015. Available at: <

http://www.themalaysianinsider.com/malaysia/article/young-muslim-women-still-fuzzyabout-sexual-rights-in-marriage $>$. Access in: 8 May 2015.

SUENENS, Cardinal. The Nun in the World: Religious and Apostolate. London: Burns and Oats, 1963.

YOUNG, Katherine K. Women and Hinduism. In: SHARMA, Arvind (ed.). Women in Indian Religions. New Delhi: Oxford University Press, 2002. 